\title{
Halina Tarkowska
}

\section{DEUS CARITAS EST}

Bóg jest miłościa, mówi św. Jan. Tak trudno, o Panie, jest przeżyć do głębi całe znaczenie tych zadziwiających słów! Bóg jest miłością, a więc wszystko, cały wszechświat został stworzony przez Miłość, w miłości i dla miłości. W chwili, która właśnie mija, Miłość jest tą wszechmocną siłą, która utrzymuje w istnieniu mnie, tego chłopa w polu, drzewa za oknami, bociana na gnieździe, okręty na morzu i gwiazdy w przestrzeni!... Miłość - Twoja miłość! — uśmiecha się do mnie z każdej spotkanej twarzy, choćby to była twarz osoby szczególnie mi niesympatycznej i Miłość wychodzi mi naprzeciw w każdym zdarzeniu dnia dzisiejszego, choćby to była tylko nieuprzejmość ekspedientki w sklepie.

Nie dość Ci było, Boże mój, że jesteś miłością sam w sobie, absolutnie szczęśliwy w miłości trzech Osób nieskończenie kochających i wzajem nieskończenie kochanych, nie chciałeś się zamknąć w swojej doskonałości. W tym okazała się miłość Boga $w$ nas (właśnie $w$ nas!), że Syna swego jednorodzonego wysłał Bóg na świat, abyśmy żylì przez Niego. W tym jest miłość, nie że my ukochaliśmy Boga, ale że On sam nas pierwszy ukochał... (I J 4, 9-10).

Jesteś miłością, Panie mój, jesteś też początkiem i źródłem wszelkiej miłości. Dlatego też nie mówmy, że nie kochamy, że nie umiemy kochać! Dla Ciebie nie ma przeszkody nie do przezwyciężenia. Takich właśnie, jak jesteśmy, nieczułych, obojętnych, ospałych, kochasz już pierwszy, od Ciebie wychodzi inicjatywa, a kochając stwarzasz nas do miłości.

Każda prawdziwa miłość legitymuje się tym, co oddaje. Jesteś od nas nieskończenie odległy - bardziej niż najdalsze ze słońc wszechświata. Dzieli nas od Ciebie więcej niźli tylko miliony lat świetlnych, dzieli nas Twoja własna nieskończoność i wieczność, o których my nawet pojęcia mieć nie jesteśmy w stanie. W Twoją miłość moglibyśmy uwierzyć ufając nieomylnemu zapewnieniu Tego, który sam jest prawdą, ale nasze ludzkie serca byłyby ciągle głodne takiej miłości, którą także one pojąć by mogły. I oto: Bóg tak umiłowat świat, że Syna swego jednorodzonego dat... (J 3, 15).

Słowo stało się ciałem i Ty-Bóg zamieszkałeś między nami, aby tłumaczyć nam swoją nieskończoną miłość uderzeniami człowieczego serca, aby przełożyć na ludzki, dostępny dla wszystkich język niepojęte doskonałości Twoje.

Syn Twój - prawdziwy Bóg i Brat nasz - prawdziwy człowiek umiłowawszy swoich, którzy byli na świecie, do końca ich umitowat (J 13, 1). Dziwne słowa Ewangelisty! Dopomóż, aby je zrozumiała, o Panie mój. Co to znaczy „umiłować do końca”? Końca czego? Chyba do końca życia i kresu sił wszystkich. Sam powiesz przecież do Apostołów: Większej miłości od tej nikt nie ma, niż gdy kto kładzie duszę za przyjaciót swoich (J 15, 13). A mówisz to, świadomy, że już nadeszła Twoja godzina. I z własnego ludzkiego doświadczenia wiesz, że większego dowodu miłości nie ma, że więcej niż wszystko dać nie można... A więc kres miłości 
człowieka Jezusa to Golgota, to oddanie całego siebie w straszliwej, krwawej ofierze w ciemności śmierci i opuszczenia.

Ale będąc człowiekiem, jesteś także Bogiem. A więc kresem Twojej miłości jest kres Twojej wszechmocy. I oto tajemnica owych słów ,do końca". Umiłowawszy swoich, umiłowałeś ich do granic własnej wszechmocy!...

A zarazem ludzkie Twoje serce czuje także po ludzku. Kiedy kogoś kochamy, pragniemy, aby był on zawsze z nami, chcemy, żeby uczestniczył w naszym szczęściu, jeśli sami jesteśmy szczęśliwi. I Tobie to uczucie nie jest także obce: Oto żegnasz się ze swymi uczniami. Odchodzisz do Ojca, wracasz do chwały swojej, którąś miał od wieczności. Ale jakże tkliwie zapewniasz swoich: Znowu przyjde $i$ wezmę was do siebie, abyście tam, gdzie ja jestem, $i$ wy także byli (J 14, 3).

W chwili trwogi przed spełnieniem ofiary myślisz, Jezu, przede wszystkim o tych swoich umiłowanych, którzy idąc śladem Mistrza, jak Ty teraz tak staną kiedyś twarzą $w$ twarz $z$ nieubłaganym wymaganiem mocnej jak śmierć Miłości. W swoim własnym sercu nosisz ich lęki, swymi własnymi nerwami odczuwasz ich odraze do tego, co ma nastapić. A jednocześnie chcesz tak bardzo - po ludzku i po bożemu - chcesz, żeby byli z Tobą razem i tu i w wieczności - zawsze! Wiesz, że tylko to może zaspokoić ich wszelkie pragnienia i tęsknoty, nawet te, przez nich samych nie uświadomione lub nie zrozumiane. I dlatego też z głębi własnej udręki zwracasz do nich wszystkich — do nas - wezwanie miłości: Jeśli kto mi stuży, niech idzie za mna; a gdzie ja jestem, tam i sługa mój będzie (J 12, 26).

Temu, kto kocha naprawdę, nie wystarcza tylko bliskość umiłowanego. On chce się z nim stopić, zlać w miłości, być jednym, ale zarazem zachować swoją odrębność na tyle, by móc nadal kochać przedmiot swej miłości. I Ty, o Jezu, nie tylko po ludzku chcesz być zawsze razem z tymi, których kochasz. Po bożemu obecny wśród nas ,po wszystkie dni aż do skończenia świata" pod zasłoną białego opłatka, czynisz nas uczestnikami swej chwały i swego bóstwa dzieląc się własnym Ciałem i Krwią i utożsamiając nas ze sobą unosisz w bezdenny ocean wewnętrznego życia Trójcy Świętej, w miłość Trzech nieskończenie kochanych i nieskończenie wzajem kochających. O to prosiłeś Ojca w Twojej wielkiej modlitwie arcykapłańskiej:

...aby wszyscy jedno byli, jako Ty, Ojcze we mnie, a ja w Tobie, aby $i$ oni $w$ nas jedno byli... Ojcze, ci których mi dałeś, chcę, aby gdzie ja jestem, tam $i$ oni byli ze mna, aby widzieli chwałe moja... (J 17, 21, 24).

Nie umiemy żyć bez miłości. Różne są definicje szczęścia, ale jakkolwiek będziemy na świat patrzeć, jedno jest pewne: człowiekowi do szczęścia, do życia potrzebna jest miłość. I szczęśliwy naprawdę może być tylko wtedy, kiedy kocha, kocha ze wszystkich sił swoich, z całego serca, z całej duszy swojej, a zarazem wie, że ukochany godny jest takiej miłości i, co więcej, że kocha nawzajem. Każdy z nas chce kochać i być kochanym - niskończenie. I cóż w tym dziwnego, skoro stworzyła nas Miłość?... I dlatego też to ,pierwsze i największe przykazanie”, przykazanie miłości, nie jest bynajmniej jakimś nakazem, obowiązkiem nałożonym na nas z góry, obcym nam i ciążącym. Dopiero wtedy, gdy je pełnimy jesteśmy w zgodzie z własną naturą, z całym światem. Co więcej, kochając upadabniamy się do Boga, uzyskujemy z Nim jakieś pokrewieństwo i dzięki temu poznajemy Go... Kto nie mituje, nie zna Boga, bo Bóg jest miłościa (I J 4, 8).

Udręczeni ciągłą pogonią za cieniem szczęścia, znużeni życiem, rozczarowani i oszukani tylokrotnie, nie wiemy gdzie szukać Boga. „Nie spotkaliśmy Go nigdy", mówimy odchodząc w własną samotność. 
O Panie, naucz mnie, naucz nas, jakie to $w$ rzeczywistości proste!... Bóg jest mitościa $i$ kto trwa w miłości, $w$ Bogu trwa a Bóg $w$ nim (I J 4, 8).

Co to znaczy ,trwać w miłości”? Słowa straciły wartość w ogólnej dewaluacji. Ale żadno może nie ucierpiało tak bardzo, jak właśnie to największe, które jest imieniem Twoim, Boże: Miłość.

Ucz nas więc dzisiaj, że miłość to nie jest owa radość budząca się w sercu matki, kiedy głaszcze główkę swego dziecka, szczęście posiadania na własność istotki tak cudownej jak ten jej mały synek. To nie jest także owa namiętność, rzucająca sobie w ramiona dwoje ludzi, dla których świat cały przestaje istnieć. To nie jest nawet poczucie, że dobrze mi tylko w bliskości tego jednego człowieka, od którego nie chcę nic więcej - byleby był i był ze mną.

To wszystko, Panie, są rzeczy bardzo wspaniałe, wszystko iskierki Twojej własnej piękności. Tu jednak chodzi o co innego. Kiedy po Ostatniej Wieczerzy żegnałeś się z tymi, co Ci byli najbliżsi na świecie, powiedziałeś im zupełnie wyraźnie: Jako mnie umitował Ojciec $i$ ja was umiłowałem. Tmwajcie $w$ miłości mojej! Jeżeli przykazania moje zachowacie, będziecie trwać $w$ miłości mojej tak, jak ja zachowałem przykazania Ojca $i$ trwam $w$ Jego miłości (J 15, 9-10). Miłość zaczyna się wtedy, kiedy przestajemy myśleć o sobie, o swojej przyjemności, swoich potrzebach, swoim szczęściu. Jedno jest tylko ważne: Umiłowany i to, czego On może potrzebować lub życzyć sobie - nawet wówczas, kiedy życzeń Jego nie rozumiemy, kiedy sprawiają nam przykrość i ból zadają. I to znaczy właśnie ,trwać w miłości”.

Wiedziałeś, Jezu, jak źle będą ludzie rozumieli słowo „miłość”. Tyleś razy ostrzegał, tyleś razy napominał, że nie ten kocha, kto tylko mówi: „Panie! Panie!” Z wyjątkowym też naciskiem mówisz przed rozstaniem swoim apostołom:

Jeżeli mnie mitujecie, przykazań moich strzeżcie... Kto ma przykazania moje i strzeże ich, ten jest, który mnie miłuje... Jeżeli ktoś mnie miłuje, słów moich strzec będzie... (J 14, 15, 21, 23).

Nie na darmo powtarzasz aż trzy razy nieomal to samo zdanie. Zdawałoby się, że chcesz wykuć w pamięci, w sercu słuchaczy tę jedną podstawową prawdę: co to znaczy kochać.

Ten, kto kocha, ma czuły słuch na głos Umiłowanego. I takie jest jedyne kryterium miłości. Nie o to chodzi, by czuć wzniosłe porywy w sercu, by duszę zalewała wdzięczność i radość. Uczucie jest tylko aureolą nad głową miłości, jasnością przyjemną, rozświetlającą nam życie i niosącą nam radość. Tego blasku i ciepła nie należy jedinak mylić z samą miłością, która rządzi wolą, a przez nią - wszystkim w człowieku. Można nic zgoła nie czuć, a mimo to kochać i to kochać miłościa bardzo wielką, jeśli tylko jest w nas gotowość każdej chwili bez zastrzeżeń na wszystko, czego życzyć sobie może Umiłowany.

Zstąpiłeś, Boże mój, na świat, aby nauczyć nas kochać prawdziwie, tak, jak Ty sam kochasz. I oto całe Twoje ludzkie życie streścił św. $\mathrm{Pa}-$ weł w jedynym zdaniu: Stat sie postuszny aż do śmierci, a śmierci na krzyżu (Fil 2, 8). Uczysz nas, Jezu, nie tylko słowami, nade wszystko uczysz własnym życiem: posłuszny woli Ojca aż do ostatecznych granic ludzkiego istnienia, aż do śmierci i to nie śmierci wygodnej i łatwej, ale strasznej na haniebnej szubienicy kzryża, wśród szyderstw wrogów i małoduszności przyjaciół.

Dlatego té̇ Bóg wywyższył Go i dał $M u$ imię ponad wszelkie imię (Fil 2, 9) mówi o Tobie dalej Apostoł. Jak Twoje własne wywyższenie i chwała sa w jakiś sposób zależne od Twego miłosnego posłuszeństwa, 
tak i Ty obiecujesz swoim uczniom nagrodę za miłość. A nagroda ta moźe być właściwie tylko jedna: za miłość płaci się miłością.

Trzykrotnie prosisz, Jezu: miłujcie mnie! trzykrotnie obiecujesz wzamian miłość: $A$ ja poproszę Ojca i innego Pocieszyciela da wam, aby zostat z wami na wieki, Ducha Prawdy... A tego, kto mnie mituje, umiz tuje Ojciec mój $i$ ja go będę miłowat i objawię mu siebie... I Ojciec mój umituje go $i$ do niego przyjdziemy $i$ mieszkanie $u$ niego uczynimy... (J 14 , $16-7,21,23)$.

Wszechmocna zaiste jest miłość, nawet ta biedna miłość serca ludzkiego! Przyjdzie do mnie i zostanie na zawsze Duch Pocieszyciel, który jest Prawdą i Miłością, umiłuje mnie Syn Boży i wprowadzi w niezgłębione tajemnice swego Bóstwa i Człowieczeństwa, umiłuje Ojciec Niebieski i oto - o Trzej!... o Trójjedyny!... Mieszkacie już w domu mym czyniąc zeń niebo swoje, świątynię, w której odprawia się tajemne, niewysłowione, odwieczne Misterium Miłości...

„Kto trwa w miłości, w Bogu trwa a Bóg w nim”.

...A najdziwniejsze, że tak niewiele do tego trzeba: tylko kochać.

Naucz nas, Panie, kochać!... Takie zwykłe, codzienne są Twoje życzenia: Chcesz, byśmy wstali rano przełamując sen i ociężałość, sprzątnęli ten pokój czy przygotowali śniadanie, pisali książkę, uczyli w szkole, przecinali bilety w tramwaju czy zamiatali ulicę... Chcesz, byśmy cieszyli się radością naszych bliskich, a czasem tak boleśnie cierpieli ich cierpieniem... Chcesz, byśmy poszli dzisiaj do kina, a jutro na pogrzeb, byśmy dziś byli zdrowi i weseli, a jutro może chorzy i pełni bólu... Wszystko, cokolwiek nas spotyka $z$ zewnątrz czy $z$ wewnątrz, wszystko przychodzi z Twojej ręki, jest darem Twojej Miłości.

Nietrudno jest zobaczyć tę Miłość w uśmiechu słoṇca na jeziorze, w młodej zieleni lasów, usłyszeć ją w śpiewie roztrzepotanego skowronka... Trudniej rozpoznać jej oblicze w wielkim ciosie, który nas miażdży i niszczy, w odejściu kogoś bardzo bliskiego, w śmierci... Ale najtrudniej chyba - w zwykłym dniu powszednim, w tysiącznych drobiazgach bardzo małych i zupełnie nieważnych, które tak boleśnie szarpią naszymi nerwami. To przykre i niesprawiedliwe słowo wypowiedziane przez kogoś, bezmyślność kolegi w pracy, przetłoczony tramwaj i spóźniający się autobus, zmęczenie i nękający ból głowy... W tym wszystkim mam uznać dary Miłości?... To Miłość każe mi spełniać codzień na nowo te same do znudzenia obowiązki?... Za biurkiem czy okienkiem urzędu, przed czarną tablicą szkoły, w hałasie wielkiej hali fabrycznej, w rozkołysanym wagonie kolejowym - wszędzie, gdzie nas umieściłeś, abyśmy w miarę naszych sił i umiejętności pełnili Twoją wolę.

Twoja wola! Na ogół mówi się o niej tylko z ciężkim westchnieniem rezygnacji: „Cóż począć? Wola Boska!..." Zdawałoby się, że ciąży ona nad nami niby nieubłagane fatum, z którym trzeba się pogodzić po prostu dlatego, że nic innego zrobić nie można.

A przecież jesteś Ojcem, który nas kocha i Twoja wola to wola Miłości. Chyba dlatego tak nam trudno, że - wbrew temu, co mówi św. Jan - nie uwierzyliśmy jeszcze Miłości!... A przecież jesteśmy Jej dziećmi i w każdej chwili, w każdym zdarzeniu, z każdym uderzeniem naszego serca, zadajesz nam, Boże, jedno pytanie, to samo, któreś niegdyś postawił Piotrowi: „Czy miłujesz mnie?"... Umieć odpowiedzieć na nie, odpowiadać zawsze $i$ zawsze wiernie, to właśnie znaczy trwać w miłości, żyé dla Ciebie.

Jako mnie posłał żyjacy Ojciec $i$ ja żyję dla Ojca i kto mnie pozywa,

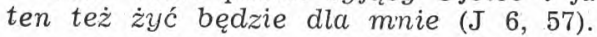


Syn Boży żyje całkowicie „dla Ojca”. Właściwie przyimek grecki „đia”, użyty $\mathrm{w}$ tekście oryginalnym (i odpowiadające $\mathrm{mu} w$ Wulgacie słówko ,propter") oznacza nie tylko cel, ale i przyczynę. Syn żyje dla Ojca i przez Ojca, On cały jest zwrócony ku Ojcu - ad Patrem. Tak jest od wieczności, w otchłaniach wewnętrznego życia Trójcy Swiętej. Tę odwieczną postawę adoracji realizuje w czasie Słowo Wcielone całym swoim ludzkim życiem.

Dopuszczając nas do uczestnictwa w nim, karmiąc swoim Ciałem i Krwią, kształtujesz w nas, Chryste, tę samą jedyną postawę: ten kto pożywa Chleb niebieski, będzie żył dla Ciebie i przez Ciebie, tak jak Ty żyjesz dla Ojca i przez Ojca. Tam, gdzie nasze siły zawodzą, gdzie kończą się ludzkie możliwości, tam Ty sam, Bóg-Człowiek, stajesz się naszym pokarmem, byśmy zaczęli żyć Twoim życiem.

A Twoje własne ludzkie życie to życie dla Ojca, nieustanne, miłosne pełnienie woli Jego. Zstapiłem $z$ nieba nie, żeby petnić wole moja, ale wole Tego, który mnie posłał ( $\mathrm{J}$ 6, 38). Nawet w Ogrójcu, kiedy cała Twoja ludzka natura będzie się wzdragać i załamywać pod nazbyt wielkim ciężarem, nawet wówczas modlić się będziesz, oblany krwawym potem: Nie jako chcę, ale jako Ty (Mt 26, 39).

Jak bardzo Ci jestem wdzięczna za tę modlitwę!... „Nie jako ja chcę"... Ubogi jest nasz język i ma tylko jedno słowo na oznaczenie dwóch zupełnie odmiennych rodzajów chcenia. W Ogrójcu Twoja wola chce mimo wszystko i wbrew wszystkiemu - tego i tylko tego, czego chce Ojciec. Ale Twoje człowieczeństwo krzyczy przeciw gwałtowi, który za chwilę ma się dokonać. To jest to drugie „chcenie”, które jednak nie jest bynajmniej aktem Twojej woli, a tylko oczywistą reakcją Twojej ludzkiej natury. Nad „chceniem” tym panuje kosztem straszliwego wysiłku wola, Twoja ludzka wola, unieruchomiona w miłości woli Ojcowskiej. Dlatego też, kiedy za chwilę ciszę Ogrodu Oliwnego przerwą wrzaski zbrojnej tłuszczy, zobaczysz, Chryste, nie tłum zbirów, ale rękę ukochanego i kochającego Ojca. I Piotra, sięgającego po miecz, powstrzymasz słowami: Czyż kielicha, który dat mi Ojciec, pić nie będę (J 18, 11).

O Jezu, Ty - człowiek, w Ogrójcu nie poddawałeś się woli Ojca z bierną rezygnacją. Wbrew całej swojej ludzkiej naturze aktywnie chciałeś tego samego, czego chciał Ojciec. „Nie jako ja, ale jako Ty!...”

Żyjesz, Synu Boży, nie tylko dla Ojca, ale i przez Ojca. Zjednoczenie Twojej ludzkiej woli z wolą Ojca jest źródłem mocy dla Twego człowieczeństwa, jest jego pokarmem. Pokarmem moim jest, abym czynit wolę Tego, który mnie posłał, abym dokonat dzieła Jego (J 4, 34).

Słowa te powiedziałeś do uczniów - do nas - do mnie! Pragniesz mi pokazać, gdzie mam szukać siły, kiedy siły już nie mam, gdzie mam znajdować moc nawet wtedy, gdy wszystko we mnie i wokół mnie się wali. Chcieć, chcieć całą mocą woli tego, czego chce Ojciec!... Ale to nie tylko recepta na wielkie nieszczęścia. Pokarmem żywi się człowiek codziennie, kiedy mu go zabraknie, słabnie, mdleje, umiera wreszcie $\mathrm{z}$ wycieńczenia...

...Ta nieproszona wizyta, ta nudna nobota, którą dziś trzeba przecież zrobić, ta denerwująca rozmowa - to Ty tego chcesz dla mnie, Twoja miłość! A zatem i ja chcę - dla tego jednego jedynego powodu (bo nie znam, a czasem nie mogę sobie wyobrazić innych!), że Ty chcesz tego.

Panie mój, jak prosta jest Twoja droga! Wszędzie i zawsze widzę tylko Ciebie, Twoją wolę, Twoje życzenie, Twoje utsawicznie powtarzane pytanie: "Czy miłujesz mnie?" I nie wiem już, gdzie się zaczyna, a gdzie się kończy moja modlitwa, bo na każdym kroku spotykam Cię, wciąż widzę Cię przed sobą i wiem (jeśli pozwolisz mi użyć twoich własnych 
słów), że ze mną jesteś i nie zostawiłeś mnie samej, bo ja to, co Tobie się podoba, chcę czynić zawsze (J 8, 29).

Powiedziałeś, Jezu, że ten Cię kocha rzeczywiście, kto zachowuje Twoje przykazania. Prawda, że Twoja wola spotyka mnie w każdej chwili, we wszelkich okolicznościach mojego życia, ale odchodząc dałeś przecież uczniom Twoje specjalne przykazanie, „nowe” jak je sam nazwałeś i czytając Ewangelię można sądzić, że mówiąc z takim naciskiem o zachowaniu Twoich przykazań, myślałeś przede wszystkim o tym właśnie.

Uprzedzasz apostołów, że rozstanie się zbliża. „Synkowie”, mówisz do nich, a właściwie jak powtarza Twoje słowa po grecku św. Jan: „dziateczki”. Ileż tkliwości jest w tym zdrobnieniu!... „Dziateczki, jeszcze tylko krótko z wami będę. Będziecie mnie szukać i - jak powiedziałem Żydom, że tam, dokąd ja idę, wy iść nie możecie - i do was mówię teraz". Słowa wstrząsnęły Twymi bliskimi. Dlatego Piotr od razu wyrwie się z pytaniem: „Panie, dokąd idziesz?”, nie zważając wcale, że razem z zapowiedzią Twojego odejścia, niejako jednym tchem, mówisz jeszcze: Przykazanie nowe daje wam, abyście się wzajemnie miłowali tak, jak ja was umiłowatem, abyście $i$ wy mitowali się wajemnie. Po tym będa poznawać wszyscy, że jesteście moimi uczniami, jeżeli będziecie mieli mitość wzajemna do siebie (J. 13, 33-35).

Nowość tego przykazania zawiera się w mierze miłości, jaką uczniowie Twoi mają mieć do siebie: ,jak ja was umiłowałem”. A więc nie wystarczy tu już stara miara: ,jak siebie samego”. A jak Ty nas umiłowałeś?... Odpowiedź jest przerażająca: tak bardzo ta miara przerasta nasze możliwości! Umiłowałeś nas „do końca” - do krwawej śmierci na Golgocie, do oddania za nas wszystkiego, co człowiek oddać może - ostatniej kropli krwi z żył, ostatniego oddechu z płuc, ostatnich resztek swego człowieczeństwa... Ale ponad to i poza tym oddajesz się do kresu czasów w ludzkie ręce jako Chleb, którym każdy może się karmić, który każdy — jeśli zechce — może nawet podeptać...

I taka ma być miara naszej miłości wzajemnej?! O Jezu, jesteś Bogiem i Wszechmocą. Dlatego tylko mogłeś takie żądanie postawić! Wiesz przecież dobrze, że my ludzie nigdy, lub prawie nigdy, nie potrafimy o własnych siłach kochać bliźniego jak siebie samego. Dobrze powiedziała Mała Swięta, tak bliska Twojemu Sercu, Teresa od Dzieciątka Jezus, że stawiając takie wymagania, dajesz od razu tym samym do poznnia, że to Ty chcesz kochać naszym sercem, że Ty chcesz sam w naszej duszy zamieszkać i naszą ubogą miłość rozszerzyć aż do granic Twojej Boskiej Miłości.

Ale chciałabym jeszcze zrozumieć, dlaczego wyznaczasz taką właśnie miarę naszej miłości. I wydaje mi się, że chwytam ten sens, kiedy rozważam pełne brzmienie Twych słów zwróconych do apostołów. Mówisz im, że odchodzisz, że będą Cię szukać... I zaraz potem rzucasz Twoje nowe przykazanie: kochajcie się wzajemnie tak, jak ja was umiłowałem. Będziecie mnie szukać, ale jeszcze na razie nie możecie iść za mną. Kochajcie się wzajemnie, kochajcie jedni drugich, bo Piotr kochając Jana, a Jan kochając Piotra, kochają naprawdę Mnie, Mnie w Janie i Mnie w Piotrze. Nie szukajcie MInie daleko, kiedy jestem tak blisko was! „Co uczyniliście jednemu $\mathrm{z}$ tych najmniejszych..." Ten, kto przyjmie Tego, kogo ja poślę, Mnie przyjmie (J 12, 20). Nie na darmo przecież zapytasz pod Damaszkiem Szawła, który Cię nigdy nie widział, a prześladował uczniów Twoich: Szawle, Szawle, czemu M $n$ i e prześladujesz?

Kiedy więc żądasz od uczniów - od nas, abyśmy się kochali wzajemnie $i$ to tak, jak Ty nas ukochałeś, prosisz po prostu o wzajemność. Za miłość Twoją do nas mamy Ci płacić miłością - mamy kochać Ciebie w ludziach, którzy nas otaczają. 
Rozumiał to dobrze św. Jan, kiedy pisał: „W tym poznaliśmy miłość Boga, że On życie swoje za nas oddał; i my powinniśmy życie oddawać za naszych braci” (I J 3, 16). „Najmilsi, jeśli Bóg nas tak umiłował, i my powinniśmy miłować się wzajemnie" (I J 4, 11).

Ty, Jezu, kochasz mnie, kochasz także pana X i panią Y. Jeżeli teraz ja nie będę kochać pana $X$ i pani $Y$, będzie to znaczyło, że Ciebie nie ma w moim sercu, bo gdybyś był, to musiałbym ich kochać Twoją miłością. Jeżeli kochamy się wzajemnie, Bóg $w$ nas jest i Jego miłość jest $w$ nas doskonata (I J 4, 12).

Tyle razy chciałabym Cię zapewniać, Jezu, o mojej miłości! Tak bardzo pragnęłabym dowieść, może nie tylko Tobie, ale i samej sobie, że Cię kocham!

„Kochajmy, woła św. Jan, bo On pierwszy nas ukochał!” Ale trzeźwy Apostoł daje zaraz praktyczną radę, która jest przecież tylko echem słów Twoich, Jezu: Jeśli ktoś powie, że kocha Boga, a swego brata będzie nienawidzit kłamca jest. Kto nie kocha swego brata, którego widzi, Boga, którego nie widzi, nie może kochać (I J 4, 19-20).

Mam więc, mój Boże, kochać wszystkich ludzi, których stawiasz na drodze mojego życia — moich najbliższych i najdroższych, moich przyjaciół, znajomych, życzliwych mi i niechętnych, nawet takich, którzy by mnie w łyżce wody utopili z radością, przechodniów na ulicy i współpasażerów w tramwaju. Mam ich kochać tak, jak Ty ich kochasz (dlatego właśnie przychodzisz do mnie codziennie), a więc kochać ich Twoją miłością, nieegoistyczną i niesentymentalną, miłością cierpliwą, która umie czekać, nie pamięta złego, z niczego się nie chełpi, zawsze ufa, wszystko znosi, wszystko przetrwa i nigdy nie umiera. A może, powiedzmy lepiej, mam $\mathrm{Ci}$ po prostu zrobić miejsce u siebie i pozwolić, abyś kochał ich wszystkich po swojemu moim sercem.

Ale to nie wszystko. Mam tych ludzi kochać nie tylko dlatego,że Ty ich kochasz, ale także dlatego, żeś się z nimi niejako utożsamił. Mam ich kochać tak, jak Ty kochasz, a jednocześnie tak, jak ja kocham Ciebie - tą samą miłością i z tych samych pobudek. Mam ich kochać dlatego, żeś Ty mnie umiłował i wydałeś siebie samego za mnie - kochać ich jako Twoje umiłowane dzieci, a zarazem jako Ciebie samego...

Jeżeli tak jest, o Boże mój, jak bardzo upraszcza się moje życie! Gdzież jeszcze miejsce na rozważania w rodzaju: czy warto zrobić to dla pana $\mathrm{X}$, bo jemu i tak nic $\mathrm{z}$ tego nie przyjdzie? czy rzeczywiście koniecznie trzeba dziś odwiedzić panią Y?... Przede mną jesteś Ty sam, Jezu mój. I słyszę zonwu Twoje pytanie: „Czy miłujesz mnie?”

Tak, wtedy i tylko wtedy mogę kochać naprawdę. Kochać każdego takim, jakim jest, bo takim kochasz go Ty, Boże mój. Kochać go dla niego samego, bo właśnie on, a nie kto innych, staje dzisiaj przede mną w Twoim imieniu. Kochać praktycznie, realnie, czynem moim i całą Twoją miłością.

I dlatego twierdzenie, które głosiło związek miłości Boga z miłością ludzi, można także odwrócić. Nie potrafimy kochać naprawde, jeśli serca naszego nie rozszerzyła, nie rozpaliła miłość Boga samego. Przez to poznajemy, że kochamy dzieci Boże, jeżeli Boga kochamy i pełnimy jego przykazania (I J 5, 2).

Boże mój, jak wspaniale brzmią wszystkie słowa o miłości!... Ile razy powtarzamy je, urzeczeni ich pięknością, pełni najlepszych postanowień. Wielbimy Twoją dobroć i Twoje miłosierdzie nad nami, obiecujemy Tobie i sobie że tym razem już dotrzymamy obietnic... Tak prędko zapominamy! Życie wciąga nas w wir swoich potrzeb, zainteresowań, radości i niepokojów. Chwila nieuwagi, lenistwa, pobłażliwości dla siebie... I oto już jesteśmy tam, skąd przyszlišmy. Znowu!... 
O Panie, jakże mi stanąć teraz przed Tobą? I cóż Ci powiem?... Ty czekasz, wiem, czekasz tylko na gest $\mathrm{z}$ mojej strony, na jedno słowo: żałuję! Ale ja wstydzę się tak bardzo, że to słowo więźnie mi w gardle. Ogarnia mnie zniechęcenie. Czyliż znowu mam Ci obiecywać, że już nie będę?...

A czasami jest to nawet po prostu nieświadomość: każesz mi decydować, postępować samodzielnie, a ja błądzę, mylę się i wybieram nie tak, jak Ty byś chciał tego. Być może, że w wielu wypadkach przesłania mi wzrok mój egocentryzm - zapatrzenie w siebie, które sprawia, iż tak łatwo nie dostrzegam innych ludzi i ich potrzeb. Potem słyszę zarzuty i znowu najczęściej nie umiem ocenić, na ile są one słuszne...

Wszystko niepokoi mnie, Panie, dręczy, powstrzymuje, kiedy chcę iść do Ciebie, wszystko mówi mi ciągle, jak złym narzędziem jestem w Twoim ręku, jak bardzo - niegodnam Ciebie, Twojej miłości i Twoich darów.

A przecież kochasz mnie, Panie, Niestrudzony Łowco Dusz ludzkich! Wystarczy choćby to tylko, że codziennie chcesz do mnie przychodzić mimo wzsystko! I jeśli nawet zabrnę tak bardzo, że czuję tylko wstręt do siebie, Twoja miłość do mnie jest zawsze tym, co we mnie - tak jak w każdym człowieku - jest piękne i godne miłości. Bo nie ma takiego grzesznika, takiego nędzarza, którego być nie kochał, Wielki Miłośniku.

W miłości swojej nieznużony obdarzasz mnie ciągle nowymi łaskami. Każda chwila jest łaską i łaską jest wszystko, co mnie spotyka. A cóż ja robię z tymi łaskami, z bezcennym darem Twojej miłości? Dajesz mi wiele, tak wiele, że chciałoby się czasem zawołać: O Panie, przestań! Boję się dnia obrachunku, bom jest niewiernym włodarzem, a sam powiedziałeś, że komu wiele dano, od tego wiele żądać będą. A jeżeli ciągle ja - my wszyscy - żyjemy pod ulewą łask, łask zapoznanych, niechcianych, zmarnowanych, co z nami będzie?... Boże mój, toć wystarczy zliczyć tylko te łaski, które strwoniłam mniej lub więcej świadomie...

Dałeś mi skarb swój — dajesz go codziennie. Mam go — ów skarb Twojej milości - i wciąż na nowo upuszczam w błoto. W bezmyślnej zabawie, w złowrogim uniesieniu rozdeptuję nogami i mam żal do ludzi, którzy mnie pytają $\mathrm{z}$ szyderstwem lub $\mathrm{z}$ bolesnym rozczarowaniem: „Gdzież jest ten twój skarb? Nie widzimy..."

O Panie, wielki Apostoł Narodów znał dobrze, aż do rozdarcia wła.snego serca, ową przeraźliwą dysproporcję pomiędzy tym, czym jesteśmy, a tym, czym Ty nas obdarzasz. „Mamy skarb ten $w$ naczyniach glinianych..." Dziwna, chciałoby się zawołać, rozrzutność, nielogiczność! Czyliż skarbu nie należy złożyć w bardziej kosztownych i mniej kruchych naczyniach? Tak by nakazywała ludzka przezorność. Ale Mądrość Boża podyktowała św. Pawłowi wyzwalające wyjaśnienie: Mamy skarb ten $w$ naczyniach glinianych, aby wspaniatość mocy była $z$ Boga, a nie $z$ nas (I Kor 4, 7).

Podoba Ci się, Panie, składać skarb Twój w gliniane naczynia, ale ma On $w$ sobie tyle mocy $i$ blasku, że glina nim prześwietlona w klejnot się przemienia.

Skarb Twół, Boże, odmienny jest od ludzkich skarbów. Jest żywy, dynamiczny - bo to Twoja miłość, Twoja moc, to Ty Sam, o Panie mój, który przychodzisz do mnie nie lękając się mojej słabości. Wręcz przeciwnie - przychodzisz właśnie dlatego, że upodobałeś sobie gliniane naczynia.

Ale i w glinie Twoja miłość jest czynna. Chcesz posiąść całe moje serce, cała moją istotę, a w tym celu musisz zdetronizować moje fałszywe ,ja”, bożka miłości własnej, którego adoruję w ukryciu. Chcesz utożsamić mnie ze sobą, abym mogła odnaleźć w Tobie moje własne 
prawdziwe „ja”, moje imię nowe, choć odwieczne, pod którym znałeś mnie już, zanim świat został stworzony.

A zatem - teraz Ty masz we mnie rosnąć, a ja się umniejszać (por. $J 3,30)$. I oto jest punkt zwrotny, chwila wyzwolenia. Któż z nas - najbardziej samodzielny i samowystarczalny - nie jest niewolnikiem własnej słabości? Któż nie przekonal się, bodaj raz w życiu, że niechętni mu ludzie, warunki czy okoliczności są potężniejsze od niego, że to, co zamierzył, przerasta jego siły, a wreszcie - i to doświadczenie ma smak najbardziej gorzki - że sam na siebie nie może liczyć, ani na sobie budować? Któż nie rozczarował się do siebie i swych możliwości - choć raz - aż do granic rozpaczy?...

A w drodze do Ciebie, Panie, nasza słabość to największa przeszkoda, mur zgoła nie do przezwyciężenia, aż wybije godzina wolności i mur okaże się bramą szeroko otwartą wprost na Twoje Miłosierdzie!

Ty masz rosnąć, a ja się umniejszać... A więc dobre jest to, co było dotąd beznadziejnie złe i bolesne, wszystko, co godzi w moje fałszywe, sztucznie wydęte ,ja”, wszystko, co je umniejsza, co je niszczy. Jeśli skarb Twój z rạk upadnie mi w błoto, to właśnie chwila, aby runąc na kolana - w owo błoto, umniejszyć się aż do samej ziemi, a pozwolisz mi skarb upuszczony podjąć, jeśli tylko on będzie dla mnie ważny. Jeżeli ludzie krytykować mnie będa słusznie - glina, - rzecz krucha i dobrze, że jej o tym przypominaja.. A zresztą choćby i niesłusznie! Każda nagana we mnie, a nie w Ciebie uderza, każda krytyka i każde upokorzenie bije w bożka miłości własnej ,a tym samym robi Ci miejsce $\mathrm{w}$ sercu moim. Moja niepewność, bezradność wobec decyzji, w trudnościach - wszystko to jakoś umniejsza mnie, zmusza do kapitulacji, do poddania... I tak krok za krokiem zrównuje się z moją własną nędzą...

Błagał Cię św. Pawéł o uleczenie z nieuleczalnej słabości. Odpowiedziałeś mu wtedy: „Wystarczy Ci łaska moja, bo moc w słabości się doskonali". (II Kor 12, 9). Moc - Moc Twoja - objawia się w sposób doskonały $w$ naszej nędzy i przeistacza ją swoim światłem. Moja jest niepewność, słabość, niezaradność i one to właśnie - dzięki Twojej łasce wśród kierowanych przez Nią okoliczności - będą drążyć stale moją miłość własną, moje falszywe ,,ja”, aż w końcu zniknę sprzed własnych oczu i będzie tylko Moc Twoja we mnie i Twoja Miłość niepodzielnie panująca.

Wszystko, co we mnie godzi, tzn. godzi w to, co przyzwyczaiłam się uważać za swoje ,ja”, wszystko przybliża tryumf Miłości Twojej. Dlatego razem ze św. Pawłem pragnę się chlubić słabością moją, aby Moc Twoja mieszkała we mnie, i cieszyć wszystkim, co mnie umniejsza, bo kiedy jestem słaba, wtedy jestem silna (II Kor 12, 9-10).

Warszawa HALINA TARKOWSKA 